\title{
Transformations in morphometry of valley bottom as a result of the creation of a reservoir illustrated with the example of Sulejów Lake
}

\author{
Marcin Jaskulski, Aleksander Szmidt \\ Faculty of Geographical Sciences, University of Łódź, Poland, e-mail jaskul@geo.uni.lodz.pl
}

\begin{abstract}
The authors have undertaken the development of DEM based on the archived materials from the time when the area of present Sulejów Lake was not an artificial water reservoir. The source materials used were Area Map of Administrative Districts in the scale of 1:25,000 from 1961 and a 1:1,000 documental map attached to the study Sulejowski Reservoir - study of sedimentation and updating of depth. The effect of this work was the creation of a Digital Geomorphological Model of the area that presently does not exist. In the second stage of works a bottom model of Sulejów Lake was made based on data gathered during echo sounding research conducted in 2008 by the Institute of Meteorology and Water Management, which comprises 36 profiles. Both models were then compared with tools available in the ArcGis program by ESRI. The analysis revealed differences resulting from processes that occurred during the construction and 40 years of existence of the reservoir.
\end{abstract}

Key words: Sulejów Lake, GIS, Digital Geomorphological Model, model of bottom

\section{Introduction}

Development of GIS methods in geomorphology as well as development and analysis of Digital Elevation Models offered new possibilities of looking at the relief of our planet. They also allowed for the development of research methods based on digital geographical data, models of the terrain. We can observe interesting results in areas where environmental changes happen fast enough to be observed during the analysed period. One of the elements of natural environment subjected to strong anthropopressure are river valleys. Valley bottoms are regulated, hydraulic structures are constructed that influence the natural geomorphological processes taking place in rivers and riverbeds.

Dams and the accompanying reservoirs are a special kind of anthropogenic objects that greatly influence the riverbed. Rich literature includes many scientific studies concerning the influence of those structures on many natural environment elements. Special emphasis is placed on the research into changes of valley relief and morphology of the riverbed resulting from building dams and artificial water reservoirs (Klimek et al. 1990, Białobrzeska, Witek 2012, Liro 2014) with respect to mountain rivers (Florek et al. 2008) and in the case of lowland rivers. Another research approach expressed in the literature are the changes within the reservoir itself. Here the main research stream, mainly because of the practical character, are studies concerning the silting up of the reservoir with sediment carried by the river (Cyberski 1970, Gładki et al. 1979, Madeyski et al. 2008, Bąk et al. 2011, Magnuszewski 2012). Those works are often purely theoretical, based only on mathematical modelling, which sometimes gives incorrect silting forecasts, after empirical verification (Lajczak 1995). There were also research studies conducted over abrasive, slope, and eolian processes occurring in littoral zones (Kaczmarek et al. 2012).

According to the authors there are few studies presenting the character of changes of the bottom of the reservoir - transformations of the river valley from its natural surface form to the bottom of the reservoir and the processes occurring there. Especially interesting is the application of GIS methodology, which allows for analyzing and visualizing subsequent stages of the changes and for comparing models based on data from different periods.

\section{Study area}

This study analyzes the valley of the Pilica River in the section between Sulejów and Smardzewice, in central 
Poland, southeast of Łódź. Presently, there is an artificial water reservoir called Sulejów Lake there. Because the area has been covered with water since the 1970s, every map presents this area as the artificial water reservoir Sulejów Lake, without presenting the relief of the area flooded with water. In order to learn about the transformations happening in the river valley, it was decided to create digital models of the Pilica valley in the area of the current reservoir from the period before its creation and now.

\section{The Pilica valley model before the creation of Sulejów Lake}

At the first stage, there was an attempt to create the Digital Elevation Model (DEM) of the presently non-existent river valley. It was decided to gather the elevation data on the basis of contour drawing, being part of topographic maps. The next step was the search for archive maps and studies containing the morphometric contents. After completing the search of archives of the Local Geodetic and Cartographic Documentation Centre and Central Geodetic and Cartographic Documentation Centre, Map Archives of the Faculty of Geographical Sciences of Łódź University and National Archives in Łódź, we chose the Area Map of Administrative Districts in the scale of 1:25,000 from 1961 and the documentation map for the reservoir in the scale of 1:1000 attached to the study "The Sulejów Reservoir - study of sedimentation and updating of depth" (IMGW 2008).

The scanned copies were given georeference in the ArcGIS 9.1 application. Due to the quality of mathematical control networks, the georeference was given first to the Area Map of Administrative Districts in the scale of 1: 25,000, which later became the calibration basis for the documentation map (Jaskulski et al. 2013). Quality of the procedure was verified by calculating the root mean square error and collation of rectified raster with contemporary topographic maps, taking into consideration only characteristic points, located beyond the flood plain of the reservoir. Scanned and georeferenced maps became the base for the Digital Elevation Model of the valley before the creation of the reservoir.

The next step was the interpretation and preparation of maps in scales 1:25,000 and 1:10,000 in ArcGIS 9.1 program and digitalization of contour drawings. According to the authors the contour drawing in the topographic maps does not give enough vertical information because it describes only terrain denivelation greater than contour interval - in this case being $1.25 \mathrm{~m}$ maximum. It became necessary to complement the data with different, more accurate geomorphological information, which are not described by contour drawing. Particular elements of the riverbed (swift currents, meander pools, meander point bars) were re-created as well as landform features in the river valley (oxbow reservoirs, banks, closed drainage de- pressions). Because of the complexity, high coincidence of fluvial events and processes, as well as the point of time when the map was made, we decided not to calculate individual parameter values of the riverbed mathematically. A procedure has been adopted to subjectively establish the axis of the riverbed and the shape of the bottom within the limits of general principles of operation of fluvial processes. After drawing the axis of the riverbed, the same method was used to introduce the riverbed depth and course values, as well as mid-riverbed point bars and meander point bars. Introduced terrain ordinates could not, however, exceed the range of contour intervals, which is $1.25 \mathrm{~m}$.

Similar procedure was used for the description of the remaining forms of the valley bottom. In the case of breaklines such as escarpments this information was introduced according to generally accepted rules. Information collected this way has been exported into a table where the X,Y coordinates were obtained from nodes of .shp files obtained in the previous stages. This data was later interpolated in the Surfer 8 program. The trials showed that with such types of data the most optimal is the natural neighbour method (Sibson 1981, Badura, Przybylski 2005, Szubert 2008). Hypsometric tints with shading were used for visualizing the relief of the Pilica valley in that period (Fig. 1).

\section{Bottom model of Sulejów Lake}

The next step was the creation of the model of the same area in its present state. Here the best way of gathering information about the form of the artificial water reservoir base is the bathymetrical analysis. Examples of such studies include the Bathymetric map of Śniardwy and Hańcza Lakes (Popielarczyk 2011, Popielarczyk, Templin 2013), as well as the Bathymetric map of Gdańsk Bay (Urbański 2006).

In accordance with the procedure, existing topographic maps are used to create the above mentioned maps, in order to digitalize the shoreline and then vectorize it and prepare in digital form. On the electronic map base prepared this way, main profile lines for depth measurements are designed. The profiles may be 5 to $50 \mathrm{~m}$ away from each other, depending on the bottom form of the reservoir and the purpose of the measurement. In the case of Sulejów Lake, it would require analysis of 360-3600 examination profiles. Then, with the use of a vessel with a GNNS devise, measurements are made that provide the depth data. The authors did not have at their disposal either such research equipment or means to order such research, therefore they decided to use the available data. For this purpose they used 36 cross sections placed at the distance of about $500 \mathrm{~m}$ from each other, attached to the study The Sulejów Lake - research of sedimentation and updating of depth (IMGW 2008). A drawback of that data was the lack of precise spatial location. The documentation map included only duration lines of the mentioned profiles, without determining their length and starting points (Fig. 2). 


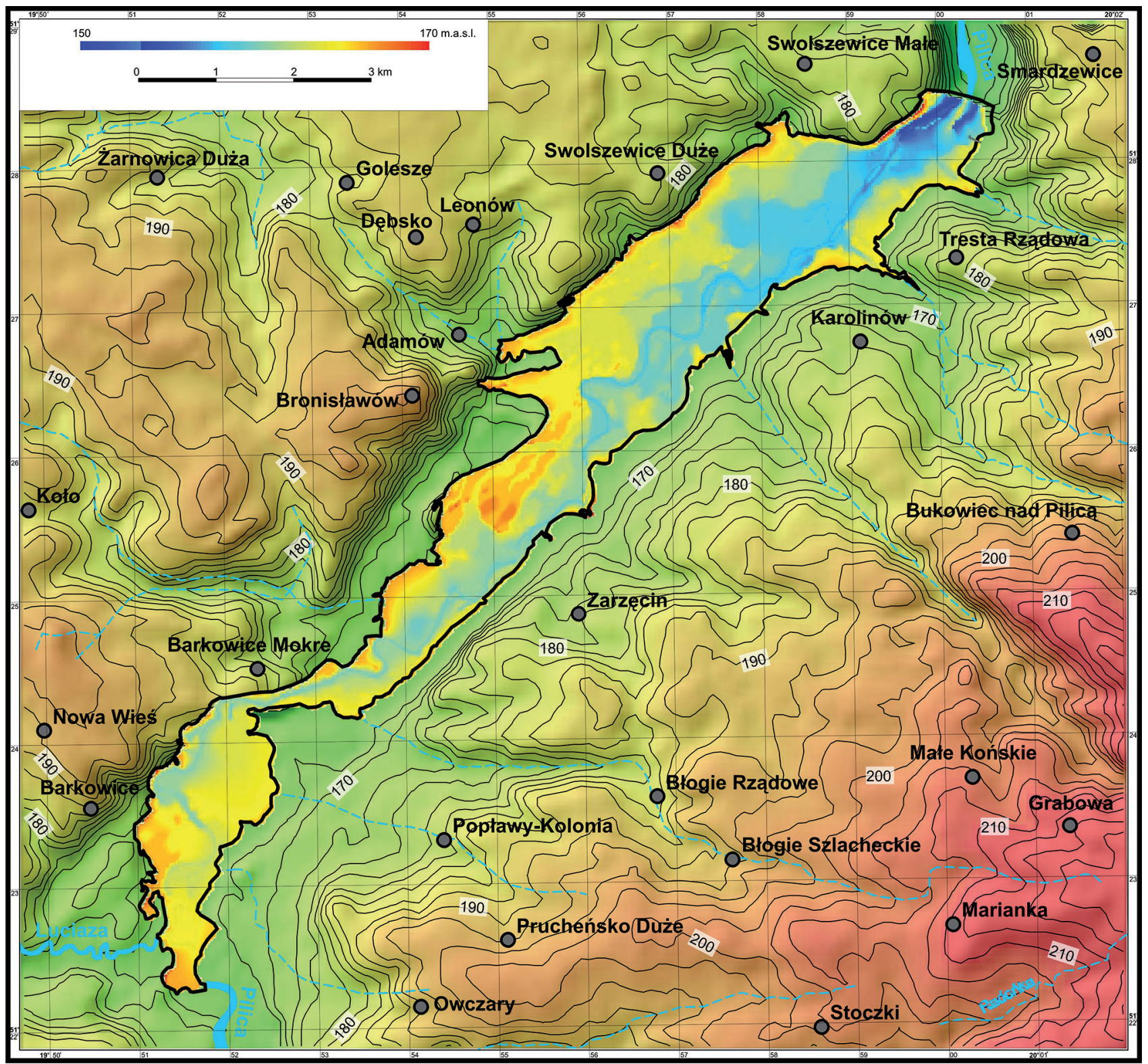

Fig. 1. Relief of the Pilica Valley before Sulejów Lake, based on historical maps

Information in the graphs, however, contained data on the relative position of the beginning and end of each profile. In order to place such data in the cartographic coordinate system with a fitting scale, azimuths of the individual lines marking the course of the profile were measured (Fig. 2). Next, the data from profile charts containing information about the distance between the starting point and the depth at the corresponding location were put into a spreadsheet. Based on trigonometric transformations, $\mathrm{X}, \mathrm{Y}$ coordinates were determined on the duration line of each profile. Based on the values calculated in such a way, a new point layer was created in the ArcGIS program, which was later put on the terrain drawing obtained from the maps. In the properties of the layer, each point was given a colour in accordance with the hypsometric tints method for making the terrain look more vivid. Next, placement of the points creating the description of the profile with the contour drawing was adjusted by shift- ing. Space fitted data from the sonar profiles became the information for making a DEM. Data obtained in this way was exported into tabular form. The data was interpolated analogically to the previous data read from topographical maps. In this way the model of the Pilica valley from 2006 was created (Fig. 3).

\section{Analysis of the terrain changes}

The next stage involved analyzing both models with the Spatial Analyst tool included in the ArcGis package. The present model was deducted from the initial model. The received raster image was scaled using the hypsometric tinted scale as: erosion - no change - accumulation. Thanks to this, a model was obtained presenting changes of the bottom of the Pilica valley from the times when it was a river valley until the present times when it is the 


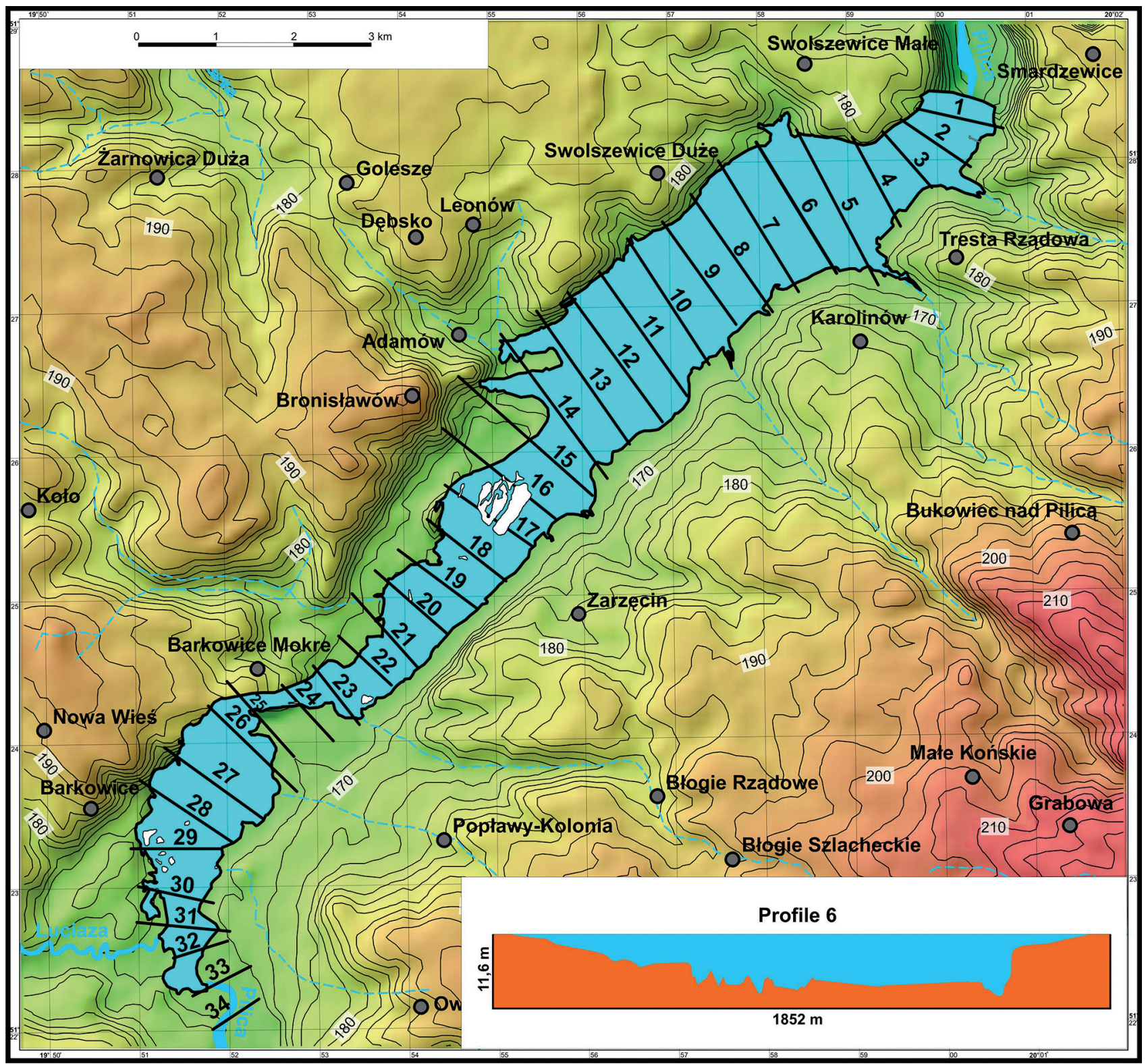

Fig. 2. Location of lines along which sonar data was obtained by IMGW in 2008 and an example profile based on the sonar data

bottom of an artificial water reservoir. Statistically, 53.8\% of the bottom area of the lake revealed no or slight depth change, not exceeding the contour line definition. 39.9\% of the area lies higher than before the reservoir was constructed, whereas $9.2 \%$ lies lower.

Geomorphological research usually proves that most sedimentary changes occur in the upper part of a reservoir (Łajczak 2006, Magnuszewski 2012, IMGW 2011). It is a result of the reservoir base level being elevated for the inflowing rivers. A characteristic feature of Sulejów Lake is two water courses flowing in the upper part of the reservoir, where this factor is intensified by overlapping the deposition of the river material as well as large morphometric isolation of the upper part of the reservoir (Fig. 1, $3,4)$. In the central and lower parts of the reservoir, the theoretical sedimentation of material carried by the river should be low enough that in many places it could be completely ignored. On the other hand, significant differ- ences in the terrain shape image and sediment thickness occur at locations where miscellaneous hydro-engineering works were conducted. The first such place is the frontal zone of the dam of the reservoir (Fig. 4). Sonar imaging reveals the existence of a large ground wall, probably related to redirecting the river during the construction works. Another example location where the image from sonar profiles shows greater depth than topographic maps is the marina zone and the intake of surface water for the Łódź agglomeration in Bronisławów (Fig. 4). In this case, the situation may be a result of deepening the exit area from the port and making water intake possible even at low water levels. The upper part of the water reservoir is a separate issue, where waters of the Pilica and Luciąża rivers meet (Fig. 4). According to the assumptions, the present bottom of the reservoir is situated higher than the bottom of the valley before the lake was built. Theoretically, we can assume that intense backfilling should 


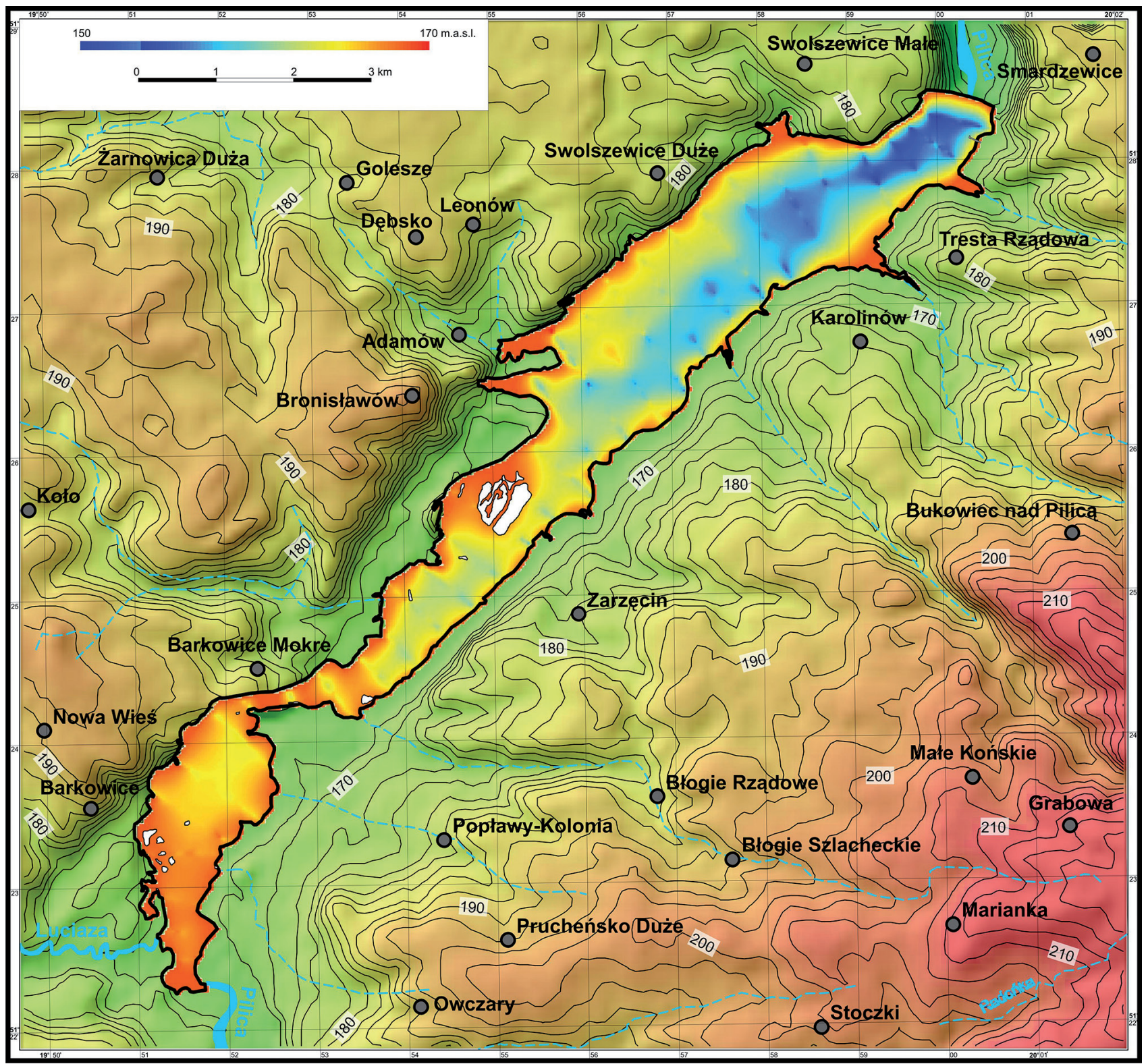

Fig. 3. Contemporary relief of the Pilica valley, based on sonar data

concern the whole upper, isolated part of the reservoir. However, results presented in the drawing of morphometry changes (Fig. 4) prove that sediment gathers along the former Pilica riverbed. This may indicate concentration of the stream in the reservoir and related disturbances of suspended matter flow. This phenomenon confirms the image of changes in the middle part of the reservoir, before shallows and islands, where water movement may be slowed down and therefore the transportation ability of the liquid may be reduced. Behind this zone, there is an area where we can observe slight changes in the shape of the bottom of the reservoir. Obviously, in the global analysis of changes, apart from sediment drifted by the rivers, we should also take into consideration the material originating from slope processes, occurring under water in the area of former undercuts of the riverbed.

However, it is obvious that differences in the image of the terrain received only from the cartographical bas- es with geomorphological interpretation containing additional data from sonar profiles, have originated due to many processes. These processes are both natural - sedimentation in the reservoir, slope and shore processes, as well as anthropogenic - caused by hydro-engineering works during the construction and use of the reservoir. Big differences may also be caused by the design of both models, e.g. the vertical resolution of the contour drawing and the sonar measurements. The very fact of having little available data from profiles created by sonic depth finder is, certainly, not without significance. For more detailed research to be conducted, access to more accurate information and technical documentation would be required, in order to isolate the anthropogenic changes related to the creation of the reservoir and auxiliary hydro-engineering structures. This would allow for the creation of a model of the bottom of the reservoir at the moment of its creation, illustrating one of the stages of the transformation. Addi- 


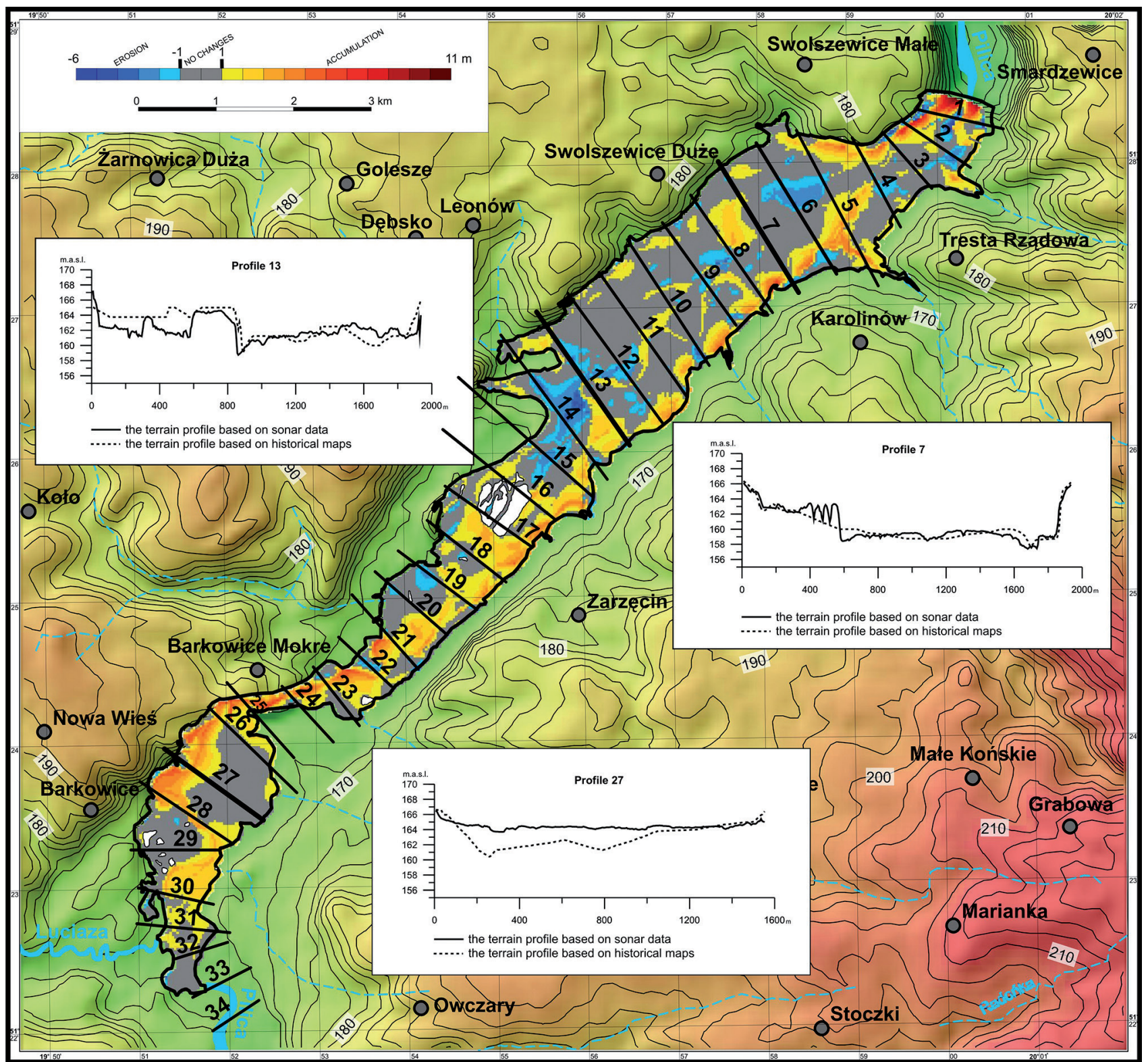

Fig. 4. Transformations in morphometry of the Pilica valley in the section between Sulejów and Smardzewice as a result of creating a water reservoir

tionally, more accurate data would be required for creating the present bottom model - for example in the form of point cloud with better spatial dispersion than targeted in the form of profiles conducted every $500 \mathrm{~m}$, or by research profiles conducted every $50 \mathrm{~m}$. This would involve making a detailed bathymetric map of the bottom according to the guidelines of the International Hydrographic Organization entitled IHO Standards for Hydrographic Surveys (IHO 2008), known under the name S-44.

\section{Conclusions}

Making two models of surface relief from different periods, made it possible to evaluate changes in the morphometry of the Pilica River valley bottom between the 1960s and the present time. Despite certain shortcomings related to different methodologies of the models, resulting from the available data that could be used, it was possible to classify different changes as natural and anthropogenic processes, occurring during the construction and more than 40 years of use of Sulejów Lake. In a little over 50\% of the area of the lake bottom, no height changes were recorded or the changes were so slight that they did not exceed the hypsometric resolution of the map. 39.9\% of its bottom lies above the level from the period before the reservoir was built, and $9.2 \%$ lies below. The changes might have occurred as a result of natural processes, e.g. sedimentation, slope and shore processes, or be caused by human activity, e.g. hydro-engineering works during the construction and use of the reservoir.

The conducted work also proves that, after inputting additional morphometric information, obtained by the authors from interpretation analyses, archival cartographic data can be used as basis for generating precise terrain surface models. Application of such data is particularly 
important in areas subjected to such relief changes, which make it impossible to utilise modern methods of obtaining height information due to anthropogenic land transformations. Models created using this method can be used as input data for analysing terrain changes originated by various natural and anthropogenic geomorphologic processes, as well as for modelling geomorphologic, sedimentation, biological and chemical processes occurring inside a water reservoir.

\section{References}

Badura J., Przybylski B., 2005. Application of digital elevation models to geological and geomorphological studies - some examples. Przegląd Geologiczny 53(10/2): 977-983.

Bąk Ł., Dąbkowski Sz. L., Górski J., 2011. Metoda prognozowania zamulenia zbiornika wodnego na podstawie pomiaru pojemności. Woda-Środowisko-Obszary Wiejskie 11(4/36): 19-29.

Białobrzeska M., Witek M., 2012. Oddziaływanie obiektów hydrotechnicznych na morfologię koryt rzek ziemi kłodzkiej w świetle analizy GIS - zarys problemu i zamierzenia badawcze. Landform Analysis 20: $103-116$

Cyberski J., 1970. Badania akumulacji rumowiska w zbiornikach retencyjnych w Polsce. Gospodarka Wodna 2: 43-46.

Florek E., Florek W., Łęczyński L., 2008. Funkcjonowanie zbiorników zaporowych na Słupi jako czynnik rzeźbotwórczy. Landform Analysis 7: 12-22.

Gładki H., Bednarczyk T., Myczka J., 1979. Prognoza zamulenia zbiornika wodnego w Rzeszowie na rzece Wisłok. ODGW Kraków.

IHO [International Hydrographic Organization], 2008. IHO Standards for Hydrographic Surveys Special Publication 4. Online: www.iho. int/iho_pubs/standard/S-44_5E.pdf - 4.12.2014.

IMGW [Instytut Meteorologii i Gospodarki Wodnej], 2008. Zbiornik wodny Sulejów badania sedymentacji i aktualizacja pojemności. MS.

IMGW [Instytut Meteorologii i Gospodarki Wodnej], 2011. Badania zamulenia koryta Pilicy w rejonie strefy cofkowej - Zbiornik Wodny Sulejów. MS.
Jaskulski M., Łukasiewicz G., Nalej M., 2013. Porównanie metod transformacji map historycznych. Roczniki Geomatyki XI(4/61): 41-57.

Kaczmarek H., Mazaeva O., Kozyreva E., Khak V., 2012. Stacjonarne badania procesów egzogenicznych w strefie brzegowej Zbiornika Brackiego (południe Syberii Wschodniej). Landform Analysis 20: 51-63.

Klimek K., Łajczak A., Zawilińska L., 1990. Sedimentary environment of the modern Dunajec delta in the artificial Rożnów Lake, Carpathian Mts., Poland, Quaestiones Geographicae 11/12.

Liro M., 2014. Conceptual model for assessing the chanel changes upstream from dam reservoir. Quaestiones Geographicae 33(1): 61-74.

Łajczak A., 1995. Studium nad zamulaniem wybranych zbiorników zaporowych w dorzeczu Wisły. Monografie Komitetu Gospodarki Wodnej PAN 8.

Łajczak A., 2006. Deltas in dam-retained lakes in the Carpathian part of the vistula drainage basin. Prace Geograficzne Instytutu Geografii I Gospodarki Przestrzennej Uniwersytetu Jagiellońskiego. Kraków

Madeyski M., Michalec B., Tarnawski M., 2008. Zamulanie małych zbiorników wodnych i jakość osadów dennych. Komisja Technicznej Infrastruktury Wsi PAN, Infrastruktura i ekologia terenów wiejskich. Kraków.

Magnuszewski A., 2012. Analiza wpływu akumulacji rumowiska w strefie oddziaływania zbiorników na bezpieczeństwo powodziowe w regionie. Określenie kryteriów wyboru miejsc przeprowadzenia prac pogłębiarskich. In: Program bezpieczeństwa powodziowego dorzecza środkowej Wisły, Warszawa.

Popielarczyk D., 2011. Application of Global Navigation Satellite System and Hydroacoustic Techniques to Safety of Inland Water Navigation. Archives of Transport 23(2): 191-207. DOI: 10.2478/v10174011-0013-x.

Popielarczyk D., Templin T., 2013. Application of Integrated GNSS/Hydroacoustic Measurements and GIS Geodatabase Models for Bottom Analysis of Lake Hancza: the Deepest Inland Reservoir in Poland. Pure and Applied Geophysics. DOI: 10.1007/s00024-013-0683-9.

Sibson R., 1981. A brief description of natural neighbor interpolation. In: V.Barnett, Interpreting Multivariate Data, John Wiley \& Sons, Nowy Jork: 21-36.

Szubert M., 2008. Geomatyka w badaniach geomorfologicznych. Dokumentacja Geograficzna 37: 7-13.

Urbański J., 2006. Batymetryczna Mapa Zatoki Gdańskiej (Bathymetric map of Gdańsk Bay). Online: ocean.ug.edu.pl/ oceju/index_mapa. $\mathrm{htm}-04.12 .2014$. 